\title{
STUDIES ON HEARING DISORDERS IN TELEPHONE OPERATORS.
}

\author{
By \\ S. HAGINO

\section{From the Department of Oto-Rhino-Laryngology, Faculty of Medicine, Hirosaki University. (Director: Prof. S. Katagiri)}

Hearing test were performed on 115 telephone operators in 1956, 134 operators in 1957, 133 operators in 1958 at Aomori Telephone Exchange Office, and on 16 operatiors in 1948 at Hirosaki Telephone Exchange Office. Following conclusion was obtained.

(1) Appearance of hearing disorders were found in $10.9 \%, 14.2 \%, 17.7 \%$, and $22.4 \%$ respectively and in over $80 \%$ of them it was perceptive nature. Moreover, about $50 \%$ of the perceptive deafness, they seemed to be hearing disörder caused by the use of recerver.

(2) About the hearing disorder due to the use of receiver, the following results were obtained.

a) More than $90 \%$ of them, hearing disorder was slight, being less than 30 db hearing loss in average.

b) The incidence was remarkable in males, who had been working oner 5 years.

c) Among the operators who had been working less than 5 years, author could not tind the cases, whose hearing loss average was morethan $30 \mathrm{db}$. In most of them, it was less than $10 \mathrm{db}$ hearing loss in average.

d) About the shapes of audisgram, author found dip-form most frequently, and next (in order of) $V$-form, U-form and gradual sloping-form. The dip was found in 44 most frequently.

e) In the cases who had been using receiver on one ear only for listening, the incidence of deafness was higher than in the cases who had beenusedon ears alter natively.

f) During 2 years' observation, an increase of hearing loss especiall in $2000 \mathrm{cps}$ at $500,1000,2000$, 4000 cps was found. But there were no cases showing improvement or progression over $15 \mathrm{db}$ in average af 4 frequencies.

g) As the result of the detailed examination, more than $70 \%$ of cases were showed positive Onchi and DL test. In the test of the speach articulation by conversation rate, more than half of the mild eases showed slight hearing disorder at $40 \mathrm{db}$ of the speach sound power. In 3 cases with moderate orsevere grade hearing loss, the disorder was observed at even $90 \mathrm{db}$.

(3) Hearing disorder of the telephone operators has the characteristics that it frequently shows the audiogram of $\mathrm{C}_{4}$-Dip. It is the authors conclusion that these facts are due to that most sound is around $1000 \mathrm{cps}$, and the energy sometimes exceeds the limit of sound criterion. 


\section{電話交換手の難聴に関する研究}

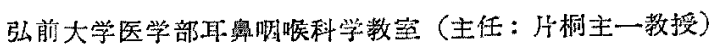

$$
\text { 萩野琞照 }
$$

目次

1 緒 高

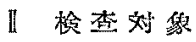

III㛟楚方法

1. 選蒯检查

2, 精泌検查

VV 検查成縝

1. 矆聴の発現淎

2. 䔣鮎の原因

3. 受話器に゙よる䔩聴

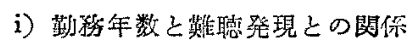

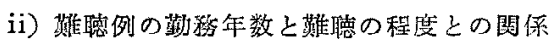

iii) 䏇力拱失の程度の分類

iv) 㙏 力 型

v) 受話器の使用耳と難㯖との関係

vi) Audiogram の推移

vii）栲密检查成維

viii) 症例

Y 総括並びに゙若按

VI 結 論

\section{I. 緒言}

近年，騥音環境の職場における彷業員の德力に関する 問題は交通々信及び諸工羓のめざましい発達に伴い，漸 く活撥に諭議されるよらになつてきた。これらの職柴珄 難聴に関しては,古くは Toynbee (1860), Roosa (1873) を始るとし，Haberman（1890），等の詳しい報告を双て いる，音響性外甥の病理については，Steinを始めとし Wittmaack, 吉井につぶき, ,Rüedi, 河田 》等の見る心゙

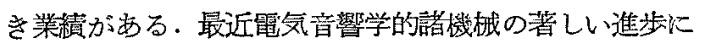

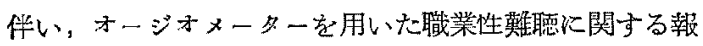
告は急激に増加してきた。電気通信㰆業の膱場に扔いて は鳃覚は最も重要な問題の一つであり, 特に電話交換手 は一定時間絶齐ず一側耳に受話器をかけて通信栄務に㹱 事しているので, それによる難腎の発現は当然教慮され なければならない、これらに関する瓡告は，我国に和い

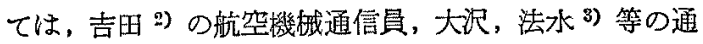
信技術員，法水，水木 等の電報局内原動所及び 電力

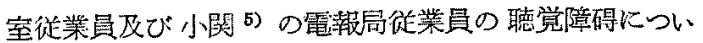

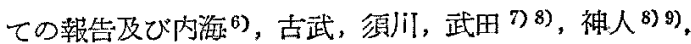

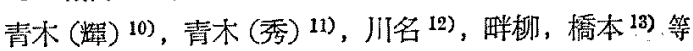
の電話交換手についての坯告があるが，詳細な検傠を加 えた報告は極めて少い，私はこの問題につき䦰心を持ら 研究を続けてきたが 14) 15)，いさ〉か知見を得たのでこ \に発表する。

\section{II. 検 查対象}

㛟查刘象は青森電話局及び弘前醋話局の電話交续手で あるが前者は昭和 31 年度 115 名, 昭和 32 年度 134 名, 昭和 33 年度 133 名につき，广た後者虫昭和 33 年度 116 名について検査を行つた、電話交換手は以前 3 号受話器 を使用し，青森局では昭和30年春より，文弘前局では 昭和 31 年冬より 4 号受話器を使用し現在に及んでいる。 これ等受話器の特性についてた後述する。なお，刘照と して青森瓝信病院女子職員（一般事務職員，薬剂師，看 護婦) 及び小鋶射整絓験安有する某自衛隊員 67 名（衛 生中隊々貝)を選えだ。

\section{III. 険查方法}

1. 選別検查

検查場所は青森聥信病院内防音室であり，永島製 $51 \mathrm{~A}$

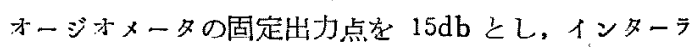
プターを使用して気導聴力について検典した，検龺暗は $500,1000,2000,4000 \mathrm{cps}$ の 種周没数とし，その中， 1 音でむ嵒えないものを難聴とし，精密検查を行つた。 この選別検查を行つた防音室の騷音は約 40 Phon であ る（先に $8000 \mathrm{cps}$ 6含めて選別したと敄告したが 14)今 回は3カ年間同じ条件に与るため，8000cps のみ低下せ る西のは除外した).

2. 精密検歪

前述の防音室队に設引られた小林式 ATー4 型簡易衈 力室を使用した。检查周波数は $125 \mathrm{cps} よ り O c t a v k$ $8000 \mathrm{cps}$ 末で, 気導立びに骨導域值檢查を行い, 他に耳 栓骨導检䀂法 (恩地法) D.L 試験及び語音检查法を適 宜に行つた。

\section{IV. 検 查成綪}

1. 難聴の発現率：難䵊の発現率（選別検查成績）は 
第1図に示す通りで，丽話交换手（青森，昭和 33 年度） に执いては 133 名中 43 名，32.3\%，266耳中 47 耳 17.7 \%であつた。これは対炤として检查した青森逓信病院女 子職貣の $15 \%$ (人数に対し) 乃至 $11.3 \%$ (耳数に刘し) 及び某自徫湴員 $43.1 \%$ (人数に対し) 乃至 $39.6 \%$ (耳数 に対し）の中間位している.耳数によるそれが，人数に 上るそれと比較して目立つて少いのは一側の難聴が多い ためである。

第 1 図

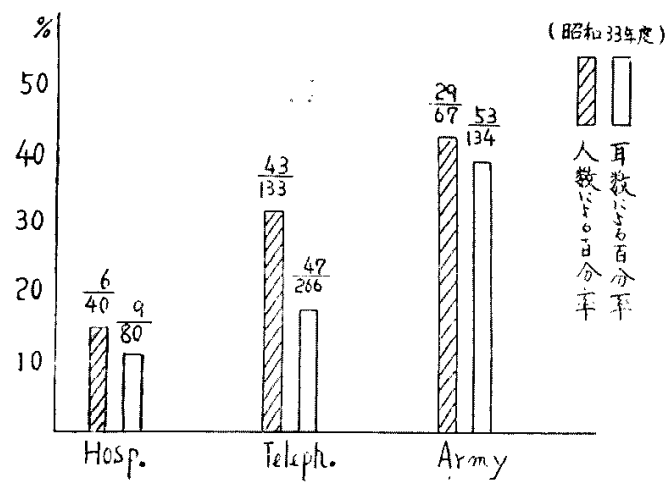

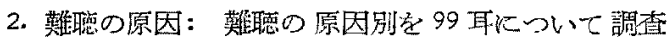

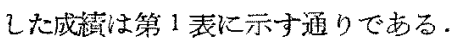

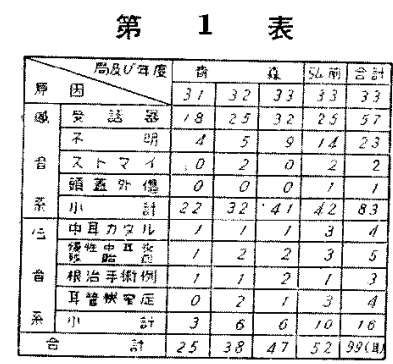

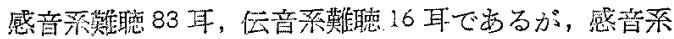
難嘼の原因は受話器によると思われるものが最も多く57

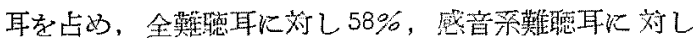
69\%で㐫り，この㑯向は各局各年度について法通で方 万.

3. 受話器による難㯖：次いでその薠聴擞のらち炤和 33 年度㺺在，受話器によると思われる難聴について調 查してみた（第2表，第了表）。

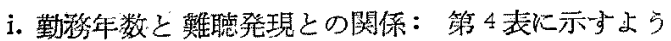

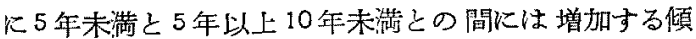
向はあるが，10年未渾と 10 年以上との閏では增加の傾
第 2 表

\begin{tabular}{|c|c|c|c|c|c|c|c|c|c|}
\hline 㛭㛭 & E & 年含 & Theas & 娶 & $f$ 型 & 程 & 臂 & 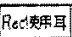 & 锥聴 耳 \\
\hline & 011107 & 268 & 109 & U & V & $1 a$ & 10 & $L<R$ & $L<R$ \\
\hline & $\operatorname{lom}=0$ & 286 & 107 & & V & & la & $R$ & $\bar{B}$ \\
\hline 3 & $10 \# 07$ & 292 & 147 & & V & & II $a$ & $R$ & $\mathrm{R}$ \\
\hline 1 & $10 \div 0>0$ & 279 & 123 & Dipc 4 & & ia & & $\mathrm{L}$ & L \\
\hline 5 & $0_{5} s_{2}: 0$ & 240 & 77 & oipCA & $0 \mathrm{PCC}$ & $1 a$ & $1 b$ & $L<R$ & $L<R$ \\
\hline 6 & 10 辰OF & 268 & 123 & U & & In $\mathrm{C}$ & & 1 & $L$ \\
\hline 7 & $\mathrm{OP}$ O & 267 & 77 & & D.PC4 & & $1 a$ & $R$ & $\mathrm{R}$ \\
\hline 8 & 0 木 $\mathrm{O}_{4}$ & 40.0 & 244 & & V & & 16 & $R$ & $R$ \\
\hline 9 & $0 \approx 07$ & 258 & 64 & & bifct & & $1 t$ & $R$ & R \\
\hline 10 & 10 今0? & 258 & 100 & V & $\mid B P C 4$ & $\sqrt{18}$ & b & $L>R$ & L \\
\hline 11 & 10良O! & 243 & 77 & & Di:PCA & & 16 & $\mathrm{R}$ & A \\
\hline 72 & O野O? & 250 & 911 & & 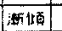 & & $1 a$ & $\mathrm{~A}$ & 8 \\
\hline 73 & 10 所 0 & 309 & 148 & & $\bar{v}$ & & $1 a$ & $\mathrm{R}$ & $\bar{B}$ \\
\hline 74 & $0=0$ 兄 & 211 & 24 & $\mid a_{1} P C 5$ & & $1 a$ & & $L>R$ & L \\
\hline 75 & 10 解口 & 288 & 14.7 & & pess & & 10 & $R$ & $R$ \\
\hline 16 & 10由 07 & 289 & 147 & DipC4 & & 18 & & i. & IL \\
\hline 71 & 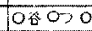 & 304 & 754 & 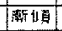 & & $1 a$ & & $R$ & $P$ \\
\hline 18 & 10 ⿴囗十 & 311 & 147 & & BPCS & & $1 a$ & A & $\mathrm{R}$ \\
\hline 79 & 0.507 & 292 & $1 \times 7$ & 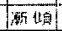 & & 16 & & & \\
\hline 20 & 1013 0 : & 260 & 911 & & v & & 18 & $R$ & $R$ \\
\hline 21 & 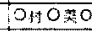 & 279 & 717 & & $\bar{v}$ & & 18 & $R$ & $B$ \\
\hline$\therefore$ & 0 源O & 242 & 7.7 & & $\operatorname{li}_{C 3}$ & & IC & $R$ & $\bar{F}$ \\
\hline 23 & O偖O织O & 226 & 24 & & $\mid$ A $P C 4 \mid$ & & 10 & $\bar{R}$ & $\overline{\mathrm{B}}$ \\
\hline 24 & 0 4⿻ 0 & 236 & 43 & OAPCA & & 10 & & $L$ & IL \\
\hline 25 & 10 it 07 & 261 & 7.7 & & $0, p c 4 \mid$ & & la & $\bar{R}$ & $\mathrm{~F}$ \\
\hline 36 & 10 e & 273 & 70.9 & & 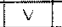 & & 16 & $\bar{F}$ & R \\
\hline 27 & $10 \geq 0 于$ & 23 & 24 & Oorcas & & $1 a$ & & 16 & L \\
\hline 28 & $15+0.0$ & 330 & 151 & $|0, P C A|$ & & $1 \%$ & & & \\
\hline 29 & $\cos 0.20$ & 27 & 23 & & 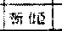 & & 18 & $\angle \& A$ & \\
\hline
\end{tabular}

第 $\mathbf{3}$ 表

(却菂局)

\begin{tabular}{|c|c|c|c|c|c|c|c|c|c|}
\hline 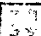 & if & $\approx$ & $x=258$ & 軳 & $\frac{p}{20}$ & $i$ & 梦 & 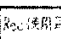 & 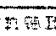 \\
\hline 30 & $10: 01$ & 23 & 29 & $u$ & & $\mid 16$ & & ? & $L$ \\
\hline$\because$ & $500 d$ & 3 & 241 & 80.804 & & 114 & & $\mathrm{~L}$ & $L$ \\
\hline 32 & 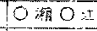 & 28 & 105 & $v$ & & 10 & & $L$ & $\mathrm{~L}$. \\
\hline 3 & O30 & 34 & 61 & $w$ & & 10 & & 1 & L. \\
\hline 54 & o㨬年 & 44 & 68 & V & & 16 & & 2 & $L$ \\
\hline 5 & 101100 & 41 & 236 & tip.94 & & 12 & & $L$ & $L$ \\
\hline 30 & $0 \% 0: 0$ & 23 & 26 & & Afen & & 18 & F & $R$ \\
\hline 27 & $10,0=0$ & 21 & 26 & 1006 & & T1a & & $!$ & L \\
\hline 38 & $10 \% 0=$ & 23 & 75 & U & & 10 & & $!$ & \\
\hline 51 & $10 \% 00$ & 26 & 61 & U & 海 & Ia & & $L$ & 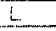 \\
\hline 10 & $0 \% 0 \% 0$ & 29 & 125 & WiPC & & 10 & & $L$ & L \\
\hline$\therefore$ & $10 \times 07$ & 27 & 100 & & U & & 18 & $F$ & $R$ \\
\hline 41 & 10坡 $0 \mathrm{~m}$ & 29 & 10 & 1094 & & $|a|$ & & L & 1 \\
\hline$\therefore 3$ & 10507 & 26 & $\therefore 6$ & & $11 P_{6} 3$ & & 16 & $\mathrm{R}$ & $\mathrm{R}$ \\
\hline 42 & D110:0 & 46 & 6.6 & & Can & & $10^{3}$ & $F$ & $\mathrm{R}$ \\
\hline 25 & $5 \ln$ & 2 & 66 & & 称 & & $1 C$ & $\mathrm{Fi}$ & $R$ \\
\hline 46 & 10007 & 2 & 29 & v & & $1 \%$ & & L. & $L$ \\
\hline 47 & 10180 & 19 & $\therefore 6$ & $\sin P 4$ & IV & 112 & $1 a$ & $L=P$ & $L=R$ \\
\hline 4 & $000=$ & $\therefore$ & i & 605 & & 110 & & $L$ & $L$ \\
\hline 49 & 020170 & 26 & $\because 89$ & 102 & & 16 & & E. & $t$ \\
\hline 50 & OBO: & 2 & 76 & wars & & 1.2 & & 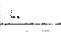 & $=$ \\
\hline 51 & 10:0 & 33 & a & int & & 18 & & $1 \ldots R$ & $L$ \\
\hline 52 & $0+0$ & 31 & 37 & 0,844 & & $1 E$ & & 1 & \\
\hline & 056 & 26 & 6.8 & V & & 16 & & & \\
\hline
\end{tabular}

问は㵔しくない。

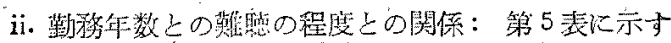

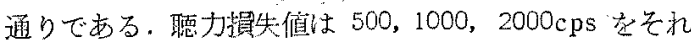
でれ $a ， b ， c$ とした場合 $\frac{a+2 b+b}{4}$ で表方している. 勤 務年数 5 年末満，5年乃至 10 年及び 10 年以上の3 群に 


\begin{tabular}{|c|c|c|c|c|c|c|}
\hline & & 第 & 5 & \multicolumn{3}{|c|}{ （昭和 33 年） } \\
\hline \multirow{2}{*}{ 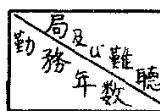 } & \multicolumn{2}{|c|}{ 青 森 } & \multicolumn{2}{|c|}{ 弘 前 } & \multicolumn{2}{|c|}{ 合計 } \\
\hline & 袷数 & 嚾聴 & 検数 & 難㯖 & 㭘数 & 難垶 \\
\hline 5年末満 & 21 & 3 & 51 & 6 & 72 & $\begin{array}{c}9 \\
(125 \%)\end{array}$ \\
\hline 5 年 -10 年 & 31 & 7 & 25 & 9 & 56 & $\begin{array}{c}16 \\
(28.6 \%)\end{array}$ \\
\hline 10年以上 & 43 & 14 & 24 & 7 & $6 \tau_{(\alpha)}$ & 21 \\
\hline
\end{tabular}

\begin{tabular}{|c|c|c|c|c|c|}
\hline 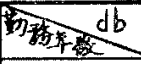 & -10 & $11-20$ & $21-30$ & $30-$ & 合計 \\
\hline 5年方满 & 5 & 3 & 1 & 0 & 9 \\
\hline 5-10年 & 3 & 9 & 3 & 1 & 16 \\
\hline 10年以上 & 8 & 9 & 1 & 3 & 21 \\
\hline 合 計 & 16 & 21 & 5 & 4 & $46(\lambda)$ \\
\hline
\end{tabular}

分けて比皎したが 5 年末临の者では婹力損失 $10 \mathrm{db}$ 以内 の整度難㯖が 遗半数を占好てい。勤務年数 5 年乃至 10 年の者及び勤㔙年数 10 年以上の者，特に前者におい ては聴力損失 10 万至 $20 \mathrm{db}$ の者が多い，なお゙，30db 以上の聴力損失者は勤務年数 5 年末満の者には認められ ず，勤務年数 5 万侄 10 年の者及び 10 年以上の者に少数 存在した。

iii. 德力損失の程度：第6 表及び第7 裴に示す通り である。第7表中 $\alpha$ とは 500，1000，2000 cps $\mathrm{a}$, b, cとした埸合の $\frac{a+2 b+c}{4} ， \beta$ とは 500,1000,2000,3000

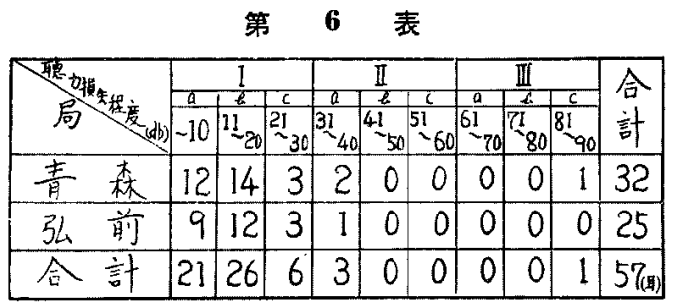

cps の平均值 $\gamma$ とは $125 \mathrm{cps}$ より $8000 \mathrm{cps}$ 运の Octav

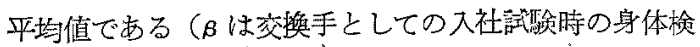
查の際に使用されるので一応参考とした)、な特，Iは $\frac{a+2 b+c}{4}$ て㯖力損失 $30 \mathrm{db}$ 未満，【は30乃至 $60 \mathrm{bd}$

\begin{tabular}{|c|c|c|c|c|c|c|c|}
\hline \multirow{2}{*}{\multicolumn{2}{|c|}{ 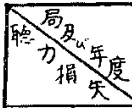 }} & \multirow{2}{*}{\multicolumn{3}{|c|}{ 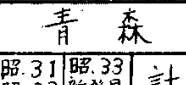 }} & \multirow{2}{*}{\multicolumn{2}{|c|}{\begin{tabular}{|l|l} 
弘前 & 合 \\
昭 33 & 耳数 \\
\end{tabular}}} & \multirow{2}{*}{$\frac{\text { 計 }}{\%}$} \\
\hline & & & & & & & \\
\hline \multirow{3}{*}{$x$} & 1 & 18 & 11 & 29 & 24 & 53 & 93 \\
\hline & I & 2 & 0 & 2 & 1 & 3 & 5 \\
\hline & II & 1 & 0 & 1 & 0 & 1 & 2 \\
\hline \multirow{3}{*}{$\beta$} & $I$ & 17 & 11 & 28 & 24 & 52 & 91 \\
\hline & II & 3 & 0 & 3 & 1 & 4 & 7 \\
\hline & III & 1 & 0 & 1 & 0 & 1 & 2 \\
\hline \multirow{3}{*}{$\gamma$} & $\mathrm{I}$ & 20 & 11 & 31 & 24 & 55 & 96 \\
\hline & II & 0 & 0 & 0 & 1 & 1 & 2 \\
\hline & 血 & 1 & 0 & 1 & 0 & 1 & 2 \\
\hline
\end{tabular}

\begin{tabular}{|c|c|c|c|c|c|c|}
\hline \multirow{2}{*}{ 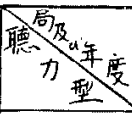 } & \multicolumn{3}{|c|}{ 青 森 } & \multirow{2}{*}{ 弘前 } & \multicolumn{2}{|c|}{ 合 計 } \\
\hline & 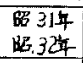 & 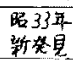 & 小訃 & & 耳数 & $\%$ \\
\hline DiP & 11 & 6 & 17 & 14 & 31 & 54 \\
\hline V & 6 & 3 & 9 & 5 & 14 & 25 \\
\hline 斩佰 & 2 & 2 & 4 & 1 & 5 & 9 \\
\hline U & 2 & 0 & 2 & 4 & 6 & 10 \\
\hline$W^{\prime}$ & 0 & 0 & 0 & 1 & 1 & 2 \\
\hline 言 & 21 & 11 & 32 & 25 & 57 & 100 \\
\hline
\end{tabular}

第 2 図

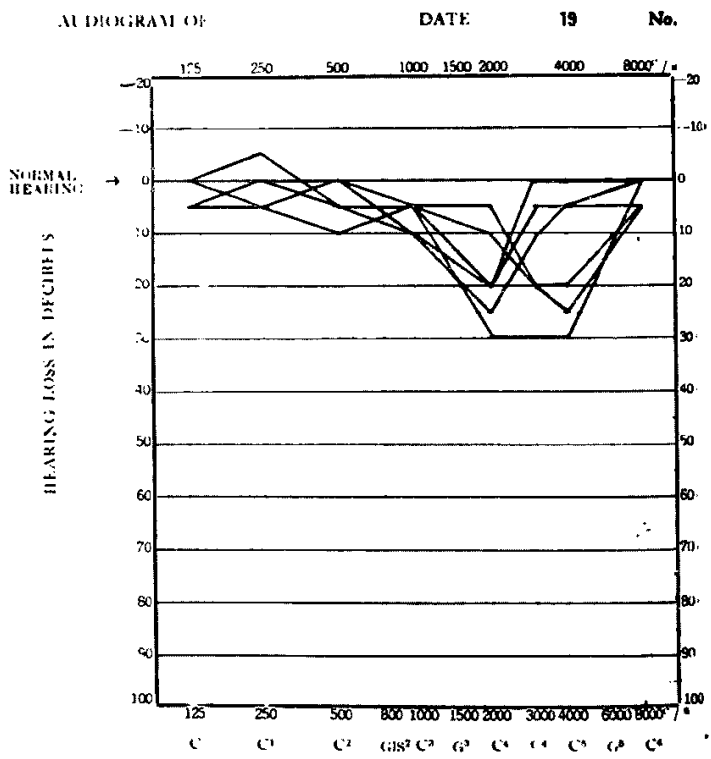

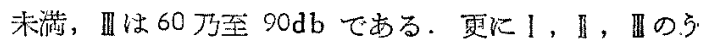
ち，暗力損失の程度によって3群比分け，比較的軽度の bの上り順に $a, b, c$ とした。青森, 弘前両局電話交換 
手共に, 大半が $30 \mathrm{db}$ 以内の軽度奞聴であつた。

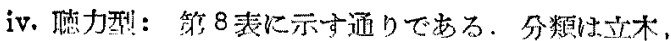
湯木，设辺 ${ }^{16)}$ 等の片泣行従つたが各局各年度において

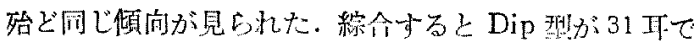
最も多く，次いでV型の14T下，U然の6耳，以下. 漱 傾型及び W 然の順になっている，Dip 型の 細別では $\mathrm{C}_{4}$ が 21 耳で最多く，次いで $\mathrm{C}_{5}$ の 8 耳, $\mathrm{C}_{3}$ の 2 耳.

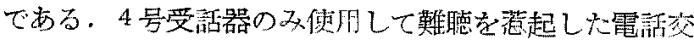
換手が青森局で 3 名 3 耳，㻆刑局で 2 名 3 耳市り，その オージオグシムは第2 図仙示寸如く2000cps 及び 4000 cpsを中心とした $\mathrm{V}$ 型， Dip 型並びにU 型を示してい る.

v. 受話器使用耳之奞罟との関係：第9表に示与通り である。交換業務に彷事してから発見された原因不明の 内耳性難㮩（例兑心゙，受話器を雨側交互に使用して一側

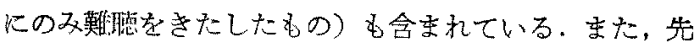

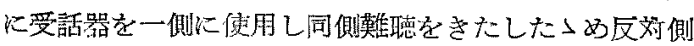
に受話器使用を変えた症例は，左右を別々に数劣た，徐 つて検查数よりその分たけ多いことになる。青森，弘前 両局共，両側使用数が一側使用数に比して少く，青森局 交換手では右側娔用者が左側使用者より多く，これに反 して弘前局交㬇手では左側使用者が，右側使用者上り多 い. また网側使用例は 102 耳中，難㯖が 11 耳で $10.7 \%$, これに対して，一側健用例では 201 耳中，難聴が 51 耳 で $25.4 \%$ 当り，前者は後者の場合より難聴の発現摔が 少小。

\section{第 $\quad 9 \quad$ 表}

（昭和 33 年)

\begin{tabular}{|c|c|c|c|c|c|c|c|c|c|}
\hline \multirow{2}{*}{ 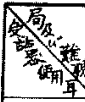 } & \multicolumn{2}{|c|}{ 青 森 } & \multicolumn{2}{|c|}{ 弘前 } & \multicolumn{2}{|r|}{ 合 } & \multicolumn{3}{|c|}{ 計 } \\
\hline & 敛数 & 難聽 & 敛数 & 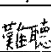 & & 数 & & 㴔 & $\%$ \\
\hline 画侧 & 82 & 8 & 20 & 3 & & 02 & & ] & 10.7 \\
\hline 一右 & 56 & 19 & 19 & 5 & 75 & & 24 & & \\
\hline 侧 左 & 39 & 10 & 87 & 17 & 126 & $<0$ & 27 & 佴 & \\
\hline
\end{tabular}

vi. Audiogram の推移：2 年間経過を旗察した12 店例 15 Fについて Audiogram の推移を钼察してみる

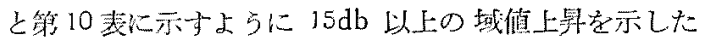
ものが 500eps については 1 例 1 耳, $1000 \mathrm{cps}$ で 3 例 3 耳, $2000 \mathrm{cps}$ で毛 3 例 3 耼, $4000 \mathrm{cps}$ では 1 例 1 耳K

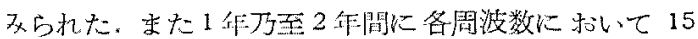
lb以上域值の下降したものは見当らず，また500， $1000,2000,4000 \mathrm{eps}$ のつの周波数のすベてが $15 \mathrm{db}$

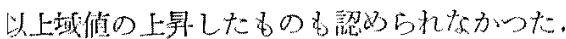

\section{第 10 婁}

\begin{tabular}{|c|c|c|c|c|c|c|c|}
\hline & & 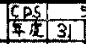 & 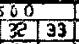 & 34 & 311 & 3 & (31) 353 \\
\hline 1 & $0\}$ & \begin{tabular}{|l|l|} 
吾 & 0 \\
\end{tabular} & \begin{tabular}{|l}
5 \\
5 \\
\end{tabular} & 1010 & 3015014 & & \\
\hline & $O \Phi O>0$ & 右 0 & & & & & \\
\hline 4 & $0.0>0$ & 510 & \begin{tabular}{|l|l|}
5 & 20 \\
\end{tabular} & \begin{tabular}{l|l}
10 & 10 \\
\end{tabular} & \begin{tabular}{|l|l|}
25 & 40 \\
\end{tabular} & $\begin{array}{l}55 \\
600 \\
\end{array}$ & 354045 \\
\hline 5 & J盃 & $\frac{\sqrt{2}}{t}$ & & & $\frac{5}{5525}$ & $\frac{20135}{3015}$ & $\begin{array}{r}15 \\
+55 \\
5\end{array}$ \\
\hline & 0 音:0子 & 55 & & & \begin{tabular}{l|l}
85 & 75 \\
8
\end{tabular} & & 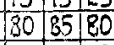 \\
\hline & 01303 & $\begin{array}{ll} & 0 \\
\end{array}$ & 50 & \begin{tabular}{|l|l|}
0 & 0 \\
\end{tabular} & \begin{tabular}{l|l|}
0 & 22 \\
\end{tabular} & 1525 & \\
\hline 9 & $0 末 0 z$ & $\begin{array}{lll}\text { 右 } & 0 \\
\end{array}$ & 00 & 0 & 5201 & $\begin{array}{l}3530 \\
\end{array}$ & \begin{tabular}{l|l}
0 & 0 \\
\end{tabular} \\
\hline & 0冷0 & $\begin{array}{|ll|}\text { 死 } & 0 \\
\end{array}$ & & & $\begin{array}{lll}0 & 25 \\
& 250 & \end{array}$ & $\frac{25}{30}$ & \\
\hline & उ良O乏 & 古 & $\begin{array}{ll}0 & 0 \\
\end{array}$ & 21 & $520:$ & 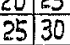 & 110105 \\
\hline & ○野○子 & \begin{tabular}{|l|l|} 
右 & \\
\end{tabular} & & & \begin{tabular}{|l|l|}
520 \\
\end{tabular} & $1 5 \longdiv { 2 0 }$ & 20120 \\
\hline & O田吸 & 10 & \begin{tabular}{l|l}
10 & 5 \\
\end{tabular} & \begin{tabular}{l|l|}
10 & 5 \\
\end{tabular} & \begin{tabular}{|c|c|}
10 & 35 \\
\end{tabular} & \begin{tabular}{l|l}
35 & 50 \\
\end{tabular} & \begin{tabular}{l|l}
25 & 20 \\
$n$
\end{tabular} \\
\hline & 0 券 $0 \%$ & & & & 5 & $3 0 \longdiv { 2 0 }$ & $I \pi$ \\
\hline
\end{tabular}

vii. 精密検查成績

a）恩地法（耳栓骨曾検查）

判定の基準は恩地の原法 ${ }^{77}$ ) 飞従い，250cps と 800 cps の2音について行い，艺れぞれ耳栓骨尊差が $15 \mathrm{db}$ 以上を+とし $10 \mathrm{db}$ から $5 \mathrm{db}$ 迄艺土， $\mathrm{Odb}$ をしし， 2 音の綜合成績を以て恩地法の判定を行つた，恩池法に よる結果は第 11 表に示寺如くである，即ち $250 \mathrm{cps}$ 及 び 800cps 2 音共に陽性のものが 32 例中 25 例 (78\%)で 最も多く，次いでいずれかか1音十，他音士の例が6例， 2 音致士が 1 例認められた。

\section{第 11 表}

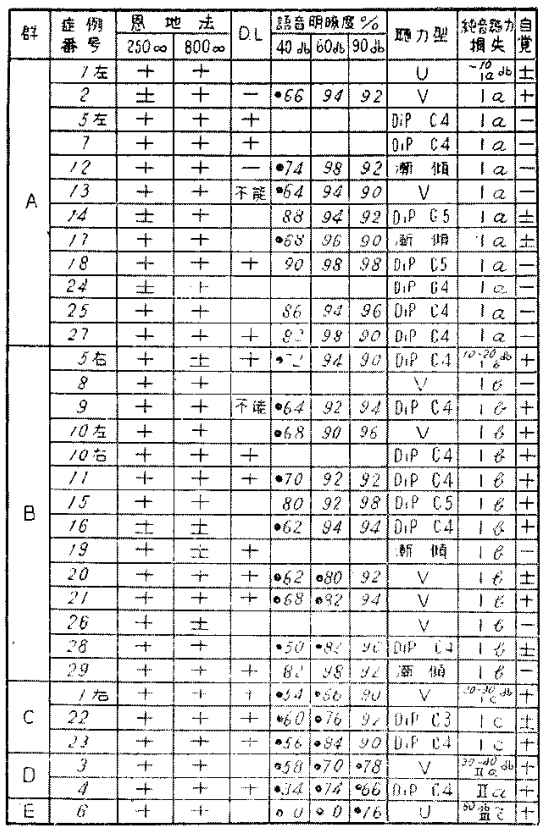

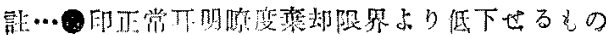




\section{b) DL 試験}

51 A オージオメーター内にある正弦波変調（cps）に 上つて域值上 $10 \mathrm{db}$ と $30 \mathrm{db}$ の 2 点で計測し, 判定に は隅田，東川，津川18）等の力法を参考とした，DLを 施行したものは19例，その中，陽性が 15 例，陰性が 2 例, 測定不能が 2 例あつた，湘定不能とは $4 \mathrm{db}$ の差で むとの差を弁別できないものを云う。

\section{c) 語音检查法}

語音明瞭度に用いた語音表は日木オージオロギー学会 聴力測定法の規蕉班で決定した 1 音節 50 語音会話率见 よるもの ${ }^{19)}$ を用いた：その結果は第11表に示す通り である，正常耳の明瞭度について検㚗した成績は $40 \mathrm{db}$ に㧅、ては平均值 $86.6 \%$ （標淮偏差 1.8 , 寨限界 93.3 $\geqq \mathrm{x} 0 \geqq 79.9$ )，60db K未いて 1.07 ，栾却限界 $99.0 \geqq \mathrm{x} 0 \geqq 92.6), 90 \mathrm{db}$ 亿打いて性平均 值 936 (標集偏差 2.41 ，寨却限界 $97.2 \geqq x 0 \geqq 90.0$ ) であ つた，難㯰耳の明膫度についてて 㭘查した成續は第 11 表 に示す如くである. 500，1000，2000 cps の純音聴力損失 をそ机ぞれ $\mathrm{a}, \mathrm{b}, \mathrm{c}$ とした $\frac{\mathrm{a}+2 \mathrm{~b}+\mathrm{c}}{4}$ の值が $10 \mathrm{db}$ 以内 の場合 ( $\mathrm{A}$ 群) は $40 \mathrm{db}$ に和いて語音聴力検查を行つ た8 例中 4 例（No. 2，12，13，17）飞扔いてその明膫度

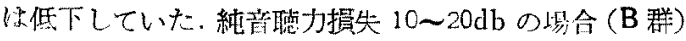

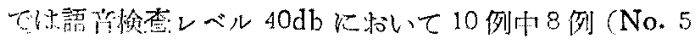

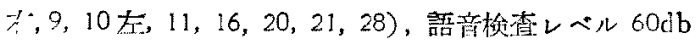

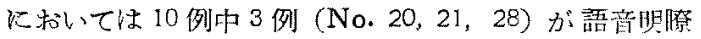
应低下を示した，純音聴力損失 20 30db (C 群) の3 例はすべて棓音レデル40db 及び 60db に执、で語音 明瞭度が低下し，純音㯖力賣失 $30 \mathrm{db}$ 以上で各レベル 洪明嘹度の箸明な低下がみられた。

viii. 症例

受話器使用により奞聴が巷起された上思われる若干の 症例について簡単に説明する。

梅毒血清反応はいずれも隍性であった。

a) $0110 子 ， 26$ 才, 症例番号 1，勤務年数 10 年 9 力

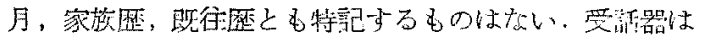

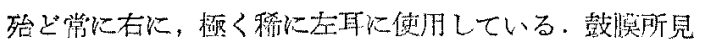

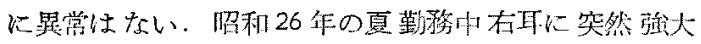

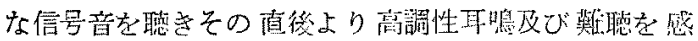

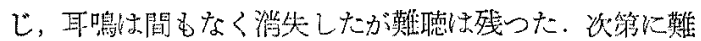

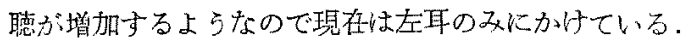

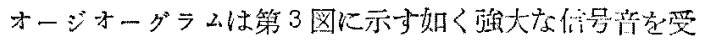

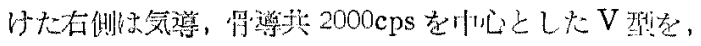

現在受話器を゙使用している左側は $2000 \mathrm{cps}$ 及び 4000 cps を中心としたU型を示している. DL Testを行つ た右側は隆性であり，恩地法は両側共に+であった。

第 3 図

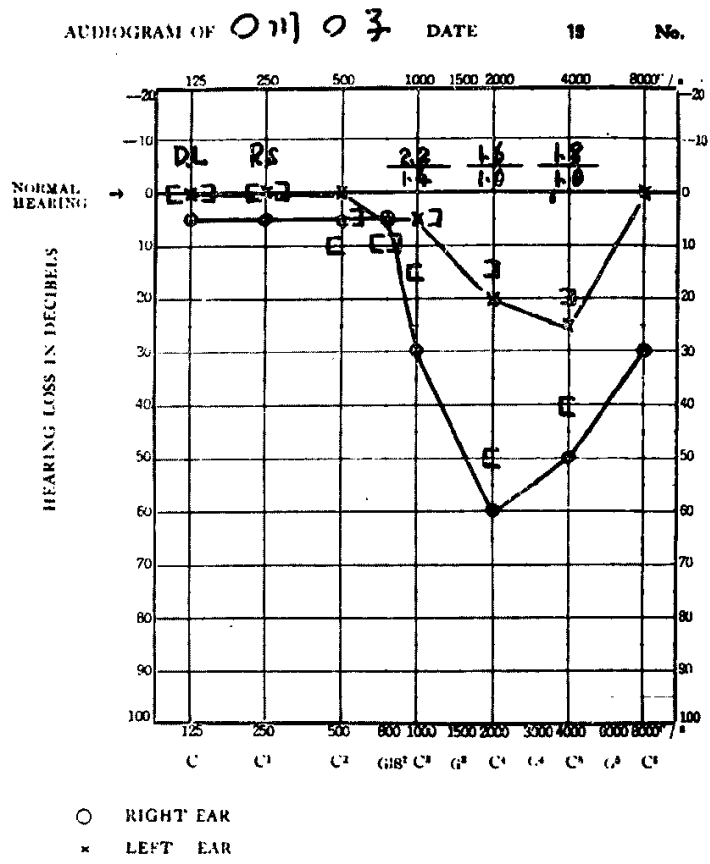

b) OHO子, , 28 寸，症例番号 16, 野務作数 14 年7 カ月，家族歴に特記事項はない，既往厢としては12年

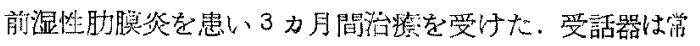

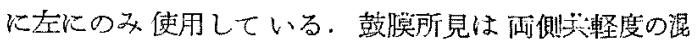
濁, 右側には症痕を認めた。昭和 30 年某日勤務中，a

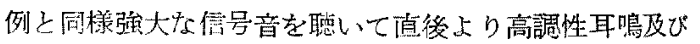

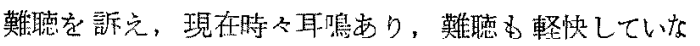
い.オージオグラムは第 4 図に示すようにa例と同しく 强大な信号音を受けた大左側に一玫して $\mathrm{C}_{4}$ Dip がみら れる、受話器を使用していない右耳は，汪ざ正常であ り，恩此洼は酒側士であつた。

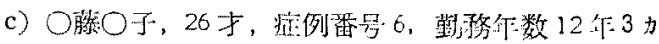
月，家族歷，既往歷比特別事項なく，又，鼓膜所見に6

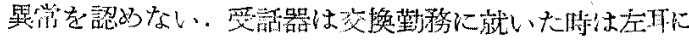

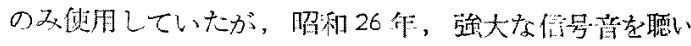
て直㷋より難聴を自覚，ピロカルピン，高解位ビタミン $\mathrm{B}_{1}$ 注射等を行つたが效果なく，現在怯右耳の文在使用 している・オージオグラムは第 5 図に示すよらに信号辛

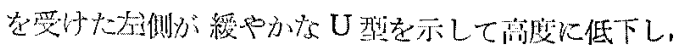




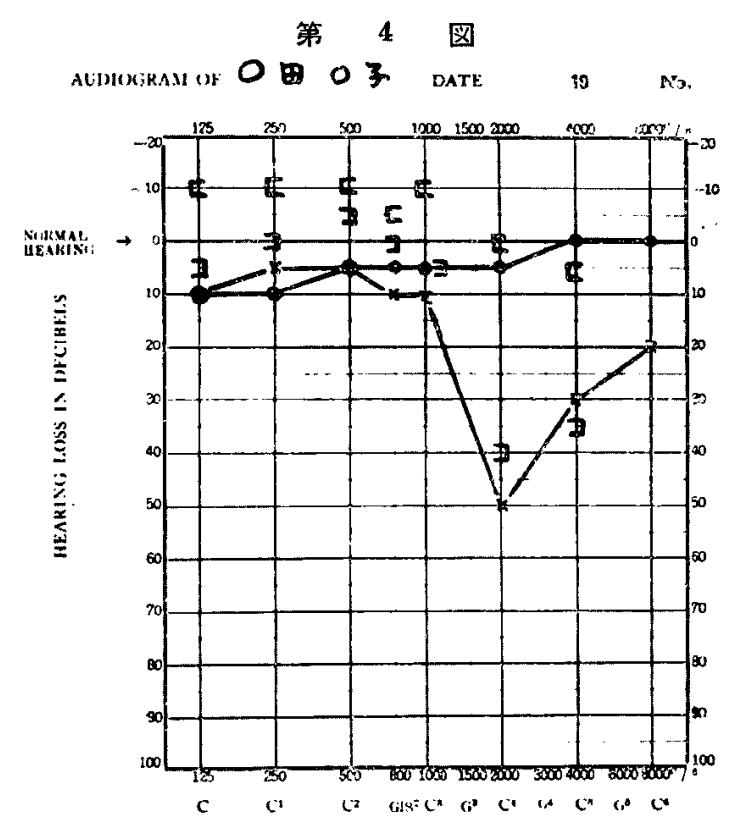

- Right EAR

* left ear

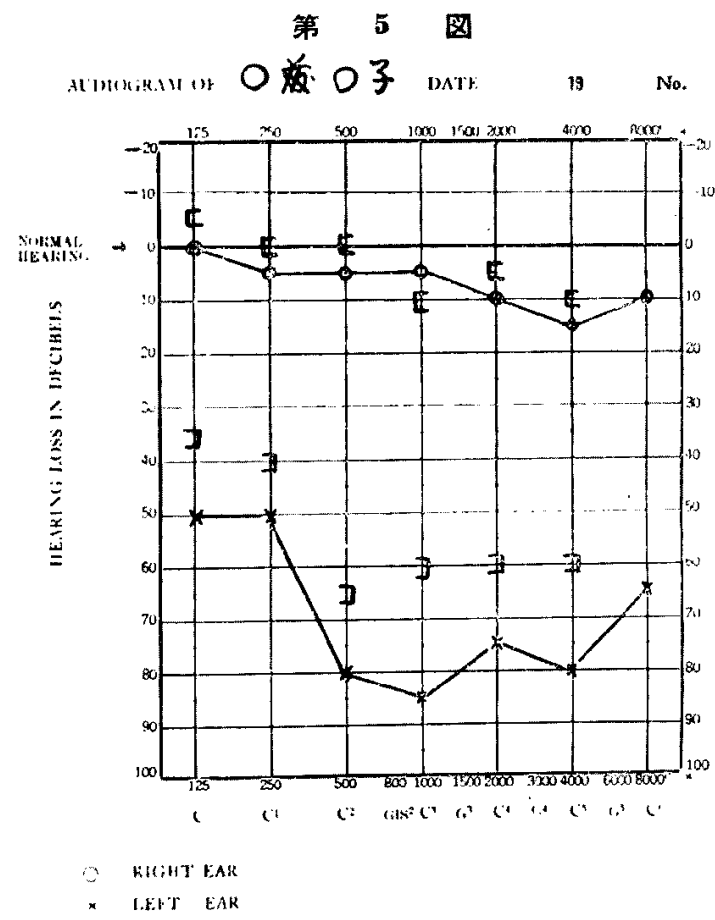

骨遒恃気導に比し，や〉軽度の低下を示している，現在 使用している右側は殆ど正常である。恩地法は两側突十
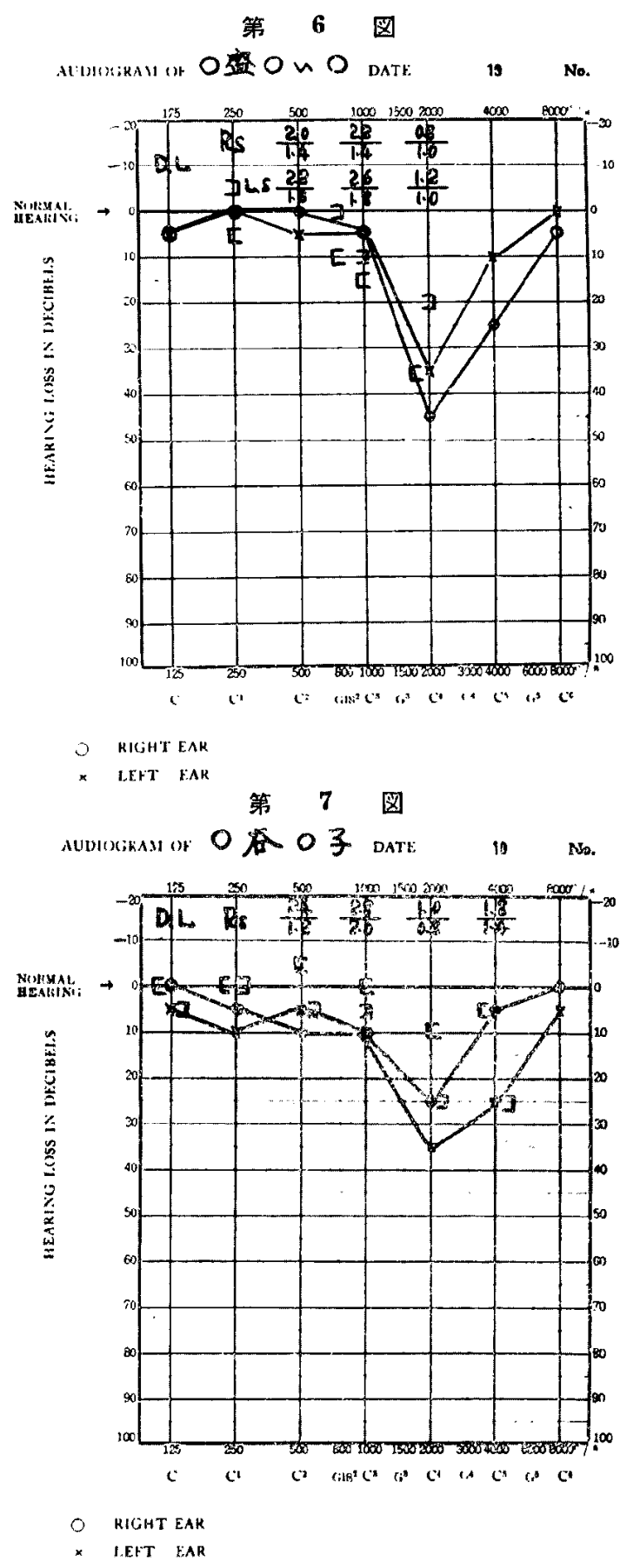

Cos\%.

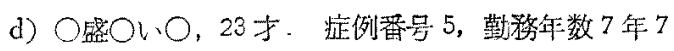

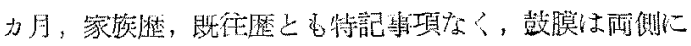




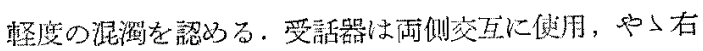

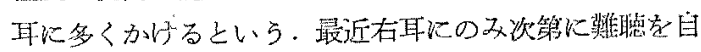

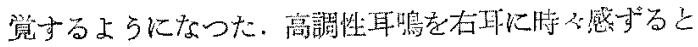

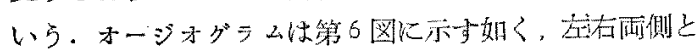

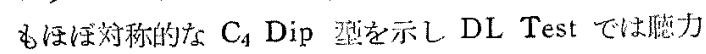

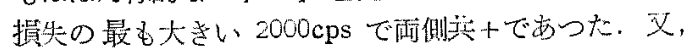

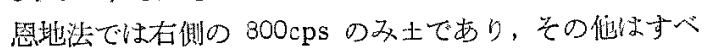
て+であらた。

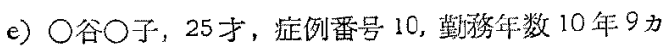

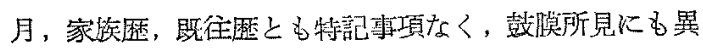
常はない，受話器は最初左側耳にのみ使用していたが次 第に難㯖劣自筧するようになり4年前より受話器を右僛 耳に代えて使用している，最近右側耳に䔮度の難喓を

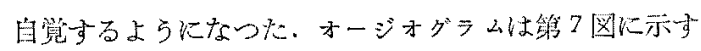

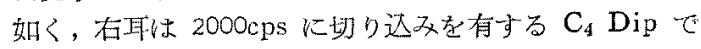

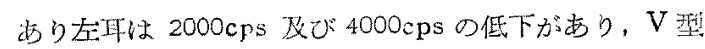
走亦している. DL Test 右耳の双について行つたが 㙂力損失の最多大きい $2000 \mathrm{cps}$ に和いて+であり，恩

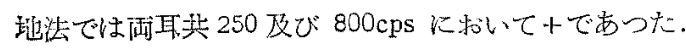

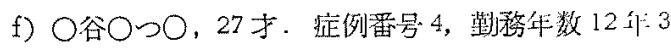

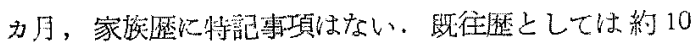

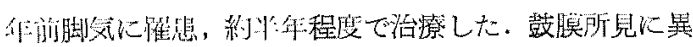

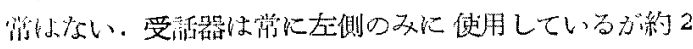

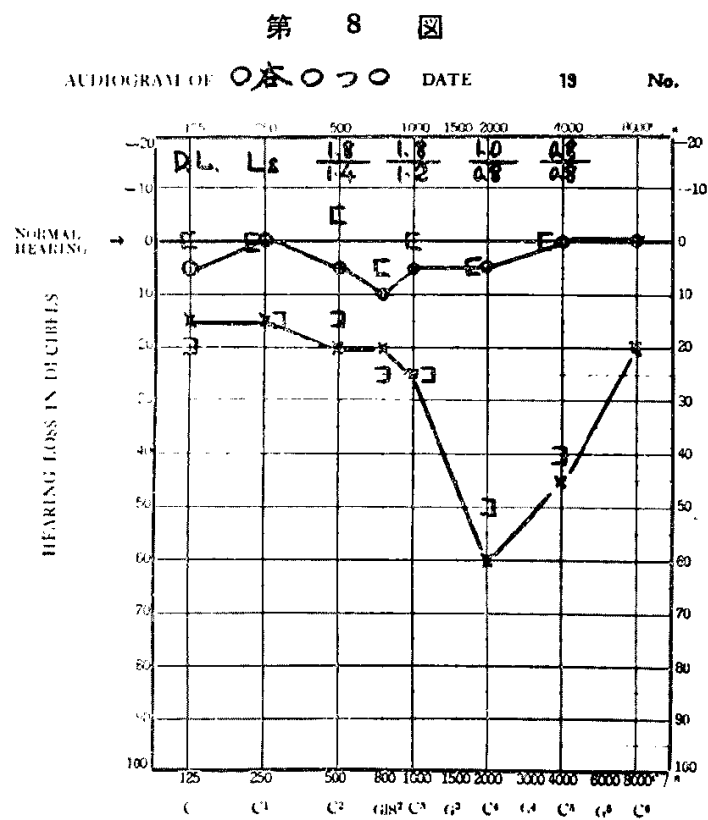

RICHT EAR

* ielt tar.

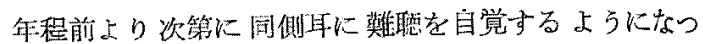

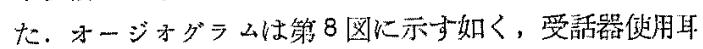

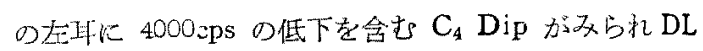
Test ては 2000cps 及び 4000ips で+であり，䍐地法 は 250cps 及び $800 \mathrm{cps}$ とむ十であつた。

g) ○解つつ，28才，症例番骂 15，勤務年数 14 年7カ

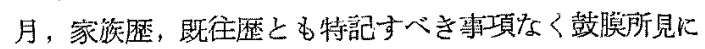

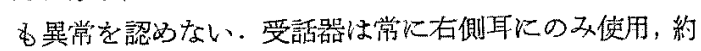
4 年程前上り次第に同側に難聴を自覚する上らになっ た、オージォグラムは第 9 図に示寸如く受話器使用の右 耳に $\mathrm{C}_{5}$ Dip がみられる。使用しない左耳正常て あった。恩地泾は 250 及び $800 \mathrm{cps}$ を耐耳十であっ だ.

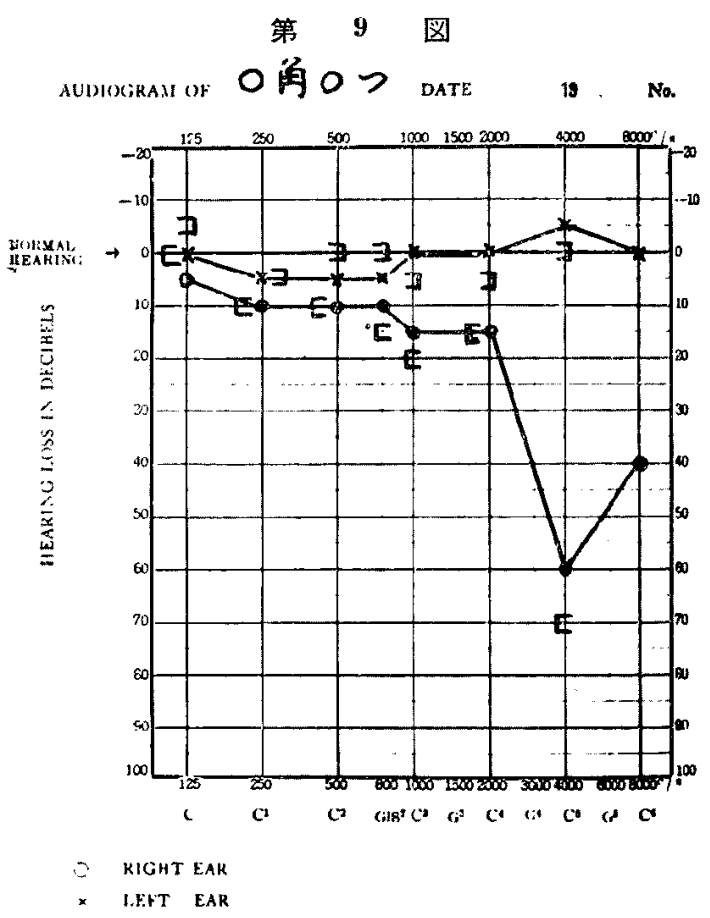

\section{v. 総括並びに考按}

先す椧查:方法について考察すると，100名以上の集団 萝力检查の場合には略式集団検查法が行われているが， その対像によつて西々異つている。即ち，造給工業職員 に哿 L, 保野, 田中, 井尻等 20) は $500,2000,4000 \mathrm{cps}$ の3 周波数で国鉄工場職員に刘して，久保，沢田等"11は 1000 及び $4000 \mathrm{cps}$ の2 周波数で電話父換手では Palva 22) は250より $6000 \mathrm{cps}$ 迄の数個の周波数で, Ji名 12)は $250,500,1000,2000,4000 \mathrm{cps}$ の 気導周波数で, それ ぞれ, Screening test を行つている。私は電々爷社入 
社基準 23）老考鎱比入れ，500，1000，2000，3000，4000

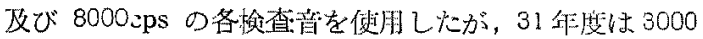

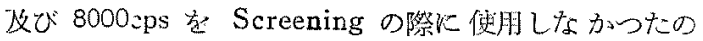
で，各年度の比較上，500，1000，2000，4000 cps D 4 栭 波数について検諳した。

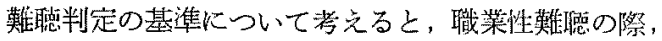
職湯健康管理上, 労働医学的に重要な子のは語音德取能 力の障䅞程度である、これについて表示する万法として は米国医学協会の力法 ${ }^{24)}$ があるが俬は我国で一般に月

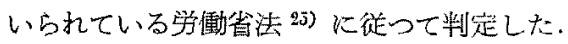

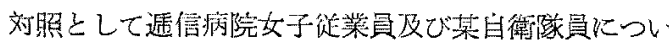
て選別した成續をも住記したが，室内騷音は聥信将院て 62〜70Phon, 電話交換公で 60〜67Phon であつた. 即

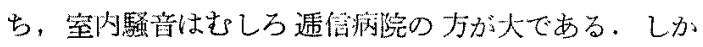

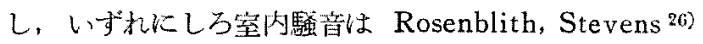

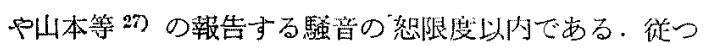

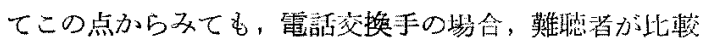

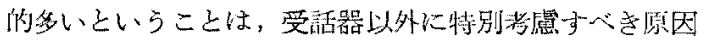

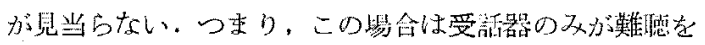

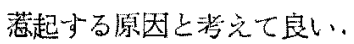

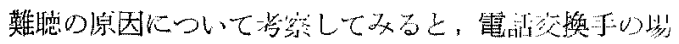

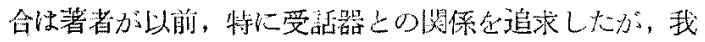

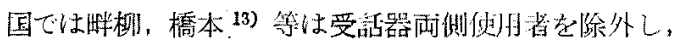

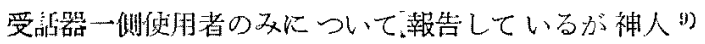
が報告したように受話器を雨側に使朋し両僛に難㢺をき

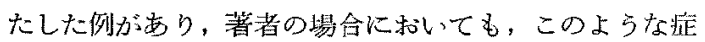

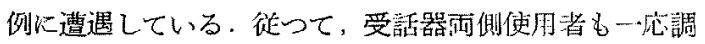
查の対象に入れた。

勤務华数と難聴発現とについて考察してみると，電話

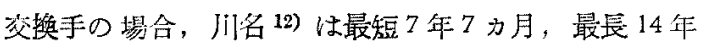
で勤務年数と難㯖度との関連は少いとし，青末 (秀) ${ }^{11}$ は難聴発現率を使用耳数についてみると勤務年数 1 年末

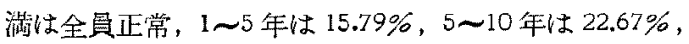

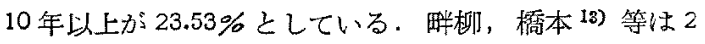
〜4年で 300 耳につき 25 耳 $8.3 \%, 5$ 7 年では 300 耳に つき 55 耳 $18.2 \% 6$, 8 年以上では312耳につき 82 耳 26.2 \%で漸進的增加を認めている。古武，須川，武田，池四 等 7)は典型的職策性蜼聴では平均 6.1 年, 最短 1.8 年で 経駺年数の長いものが多く難聪に曜つているとしてい

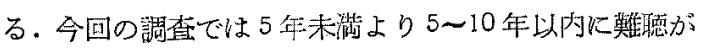
多いが，5年〜10 年と 10 年以上との間には殆ど 差がな かつた。しかし難聴の程度は睢聴者のみについてみれ

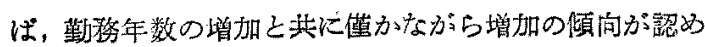

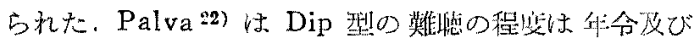

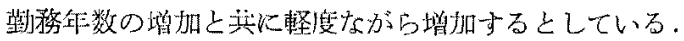

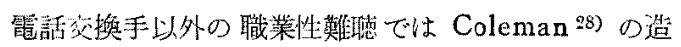

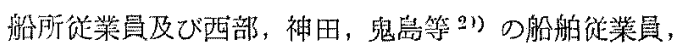

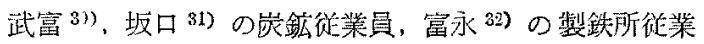
貣についての諸調查報告をみるが，いずれも淽務年数と 難咕数との間に时睹な相関ありとしている。しかし， Sirrala, Lahikainen ${ }^{33}$ ), 河田 ${ }^{1)}$ ，武富 ${ }^{34)}$ 等のい弓如く その中でも職酤によつてかなり差が認められるようであ る.

㮩力型について若干の考察る加充てみると，電話交换 手の星合では畔楖，橋本 ${ }^{13)}$ の身京都市外局についての

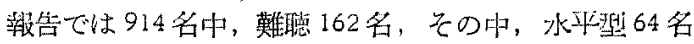
$39.6 \%$, 漸傎问 39 名 $24.1 \%$, Dip 型 24 名 $14.1 \%$, 急傾

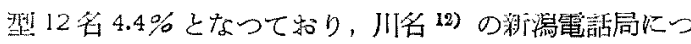

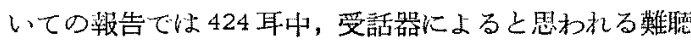

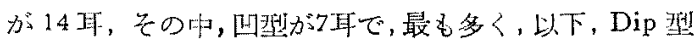

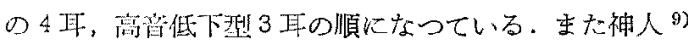
の和歌山電部司についての報告では198各中, 受部器に

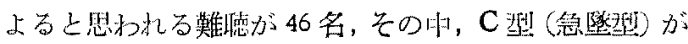

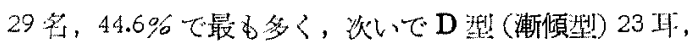

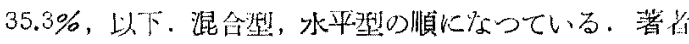

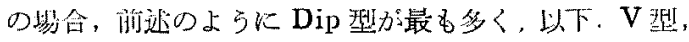

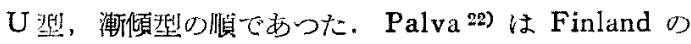
Turku の電部父換手について謂查し，139 例中受話品

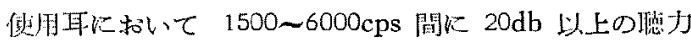

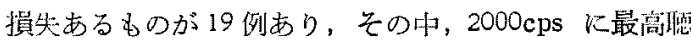
力䭫失を有主るものぶ9例で最も多く，次いで $3000 \mathrm{cps}$ の5例，以下，4000攵び $1500 \mathrm{cps}$ 例と報告してい るが著者の場合も2000cps Dip が最も多く, 次いで 4000，1000cps であつた。 秀た，畔柳，橋本 (3) の報告 でも2000cps Dip が最も多く，以下 $3000 ４ 000$ cps Dip であつた，即ち，Dip 型について考兄れば，あきらかに

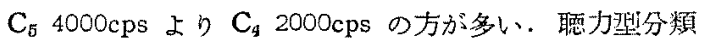

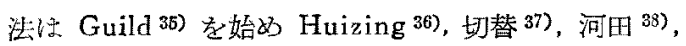

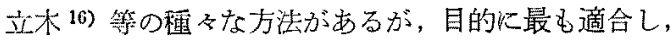
且つ，臨床的に容易に使用し得る普扁的なものといら考 えに立つた立术等の方法 16) を使用した，電話效換手の

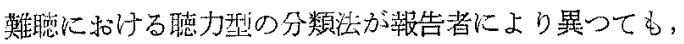
前速の如く $\mathrm{C}_{5}$ Dip \&り $\mathrm{C}_{4}$ Dip が多いのは注目けベ き牙であり，この点について填をあらためて述べる。

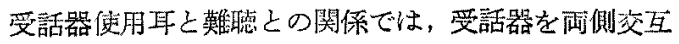
に位用し，次第にその中一側のみに漸進的に難㯖をきた 
した者もあるがこの崵合は受詰器によるかどうかは今後

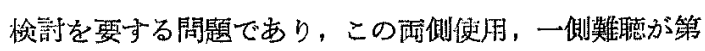
9 表の中，活側交互便用闌に 5 耳含をれているが，第 1 表の難聴の原因別の表では原因不明として記入し，第 2 表及び第 3 表には含まれていない。

診断の確実を期するため，精密検查をを行つた。即占， 骨導域值検查, 耳棱骨導法, DL 検查法検查法欧び語音

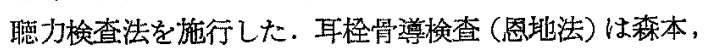

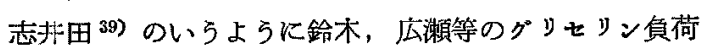
検查法と共に簡易にして，しかも，相当嘊实性を有方る ので便用した，DL Test には Intensity Difference Limen と Frequncy Difference Limen とあるが, 私の用いたのは Jeger ${ }^{40)}$, 恩地 ${ }^{41)}$, 志井田 ${ }^{43)}$ 等の域值 上の2点について計测する Intensity Difference Limen Test である. DL Test が陽性の場合は BalanceTest と同稼に内耳障碍の存在を示唆する有力な証拠之 されているので本検查を試みたが, 陰性 2 例, 檢查不能 2 例，その他はすべて陽性であつた。

語音聴力袷查法に関しては，従来我国では河田 ${ }^{43)}$ ， 岡本44）をはじめ; 幾多の報告があるが 1957 年，聴力 測定規準委員会で决定された方法 ${ }^{199}$ に準じて測定した。 語音聴力検查の装置としてはテープレコーダーを使用し 受話器より聴取させた，電話交換手が実際に聴取する語 音の大きさは第 12 表に示すように青森局に执いては市 内線で 65 90db であり, 長距離よりの德取の場合は 35〜60dbであつた，それ故，この電話交换手が受話器 を通して恥取ざれている語音のレデルの3 点, 即ち 40 , 60 及び $90 \mathrm{db}$ によつて語音眲力検查を行い正常者之 此輘してみた，著者は気尊聴力について，500，1000， $2000 ， 4000 \mathrm{cps}$ の中，一種類です $20 \mathrm{db}$ 以上の䎸力損失

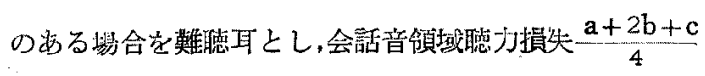
の値が $10 \mathrm{db}$ 以下の場合, 即ち，A 群(第11表) の中,

第 12 表

\begin{tabular}{|c|c|c|c|}
\hline & 4号受話器 & 3号受話器 \\
\hline \multirow{2}{*}{ 短 } & 市内 & $65 \sim 85$ & $70 \sim 90$ \\
\hline & 浅虫 & $50-65$ & $55 \sim 70$ \\
\hline \multirow{2}{*}{ 距 } & 野辺地 & $45-60$ & $50-65$ \\
\hline & 三呮 & $40 \sim 60$ & $45-65$ \\
\hline 亮 & 仙夋 & $40-55$ & $45-60$ \\
\hline 漓 & 東京 & $35-50$ & $40^{\circ} \sim 55 \mathrm{db}$ \\
\hline
\end{tabular}

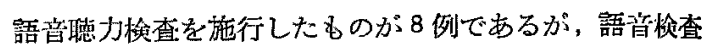
レベル $40 \mathrm{db}$ に和いては正常耳に比較し，No.2, 12, 17 に語音德力の低下が認められ No. 14，18，25，27 Кは 語音聴力の低下は認められなかつた，即ら，前涽の純音 聴力損失を見るに No. 2, 12,13，17等は 2000，4000 cps 共 $20 \mathrm{db}$ あるいはそ的以上の低下があるのに対し, 後者 の No. 17, 18 は 4000cps のみ夫々 20db，25db の衈 力損失を有し, No. 25,27 は 2000 cps のみ $20 \mathrm{db}$ の衈 カ損失を有するに過ぎないことが語音聴力に関連してい るものと思了。B洋（第 11 表）は $10 \mathrm{db} \sim 20 \mathrm{db}$ の純音 㯖力損失を有する症例であるが，その中，10例俉音 聴力検查を施行し，語音検㸖レベル $40 \mathrm{db}$ に特いて8 例に語音聴力の低下が認められた。語音㯖力の低下を示 さなかつた 2 例は，400cps Dip 及び漸頃型の名 1 例で あった．C群（第11表）の3例は 20db〜30db の純音 德力損失を有する症例であるが語音検查レテル $40 \mathrm{db}$ 及 び 60dbに赫いて全例に語音聴力の低下がみられた。

No. 3 及び No. 4 の 2 例㤝 $30 \sim 40 \mathrm{db}$, No. 6 は $84 \mathrm{db}$ の純音聴力損失を有する症例であり，聴力損失 $30 \mathrm{db}$ 以 上ではいす゚机も明瞭修の低下がみられたがその最高明膫 度は 50\% 以上を示した。唯, No. 6 のみは 90db K顿 いて、わずか 16\%の明瞭等を示したに過ぎなからた。 即ら，稀ではあるが受話器使用により，かなり高度の難 聴をきたしした例があるといらことは注目すべき事だと思 う、をた，受話器より恥取される語音のらち、此較的音 声出力の弱、長距離回線に従事する場合, 言語周波数帯 域に 1 個所でる20db 以上の純音恥才損失のある交换手

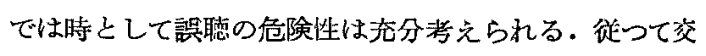
寏業務に支障をきたす可能性もあると考えられる。

$2000 \mathrm{cps}\left(\mathrm{C}_{4}\right)$ Dip k詨する一考察

電話交换手の聴力障得に $\mathrm{C}_{4} \mathrm{Dip}$ が多いことは決目 ずべきことである：この点に関し，その成因を溚察した い，先省青森局交奐手 55 名にアンケートを求め，受話 器より聴取する音源のうち, 特に不快感を与えるものを 澗查したところ, Click が最も多く26名，47\%，次い で信号音で 20 名, $36 \%$, 音声が最も少く9名, $16 \%$ で あった.そこで、これらいつの不快感を与える音源のう

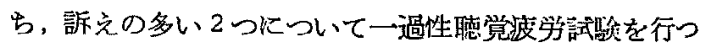
てみた。被检者はいずれる20才代の聴力正常者であり； 刺战持繶時間は 5 分間とした。

先ず聴力正常者 4 名 4 耳に刘し1粆間に2 回づつ Click の刺战を与えた場合の德覚域值変動は第 13 表に 示す如くである. 即ち，3号受話器の場合, 刺㦸負荷直 
第 13 表

\begin{tabular}{|c|c|c|c|c|c|c|c|c|}
\hline \multirow{2}{*}{$x^{2}$} & \multicolumn{4}{|c|}{ 3是受話量 } & \multicolumn{4}{|c|}{ 4婜受竦器 } \\
\hline & 500 & 1000 & 2000 & 400 & 150 & 1000 & & \\
\hline 真后 & 0 & 5 & 5 & 5 & 0 & 5 & & \\
\hline 万人捾 & 0 & 0 & 0 & & & 0 & 0 & \\
\hline 真后 & 0 & 0 & & & & 0 & 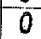 & 0 \\
\hline 20 & 0 & 0 & 0 & & 0 & 0 & 0 & 0 \\
\hline 西后 & 0 & 0 & 10 & 5 & 0 & 5 & 10 & 10 \\
\hline 徍的 & 0 & 0 & 0 & & 0 & 0 & 5 & 5 \\
\hline 值后 & 0 & 5 & 5 & 0 & 0 & 5 & 5 & 0 \\
\hline & 0 & 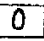 & 5 & 0 & 0 & 0 & 0 & 0 \\
\hline
\end{tabular}

後に域值上景を示したものは $1000 \mathrm{cps}$ 及び $4000 \mathrm{cps} に$ 括いて 2 例保 $5 \mathrm{db}$, 㕛 $2000 \mathrm{cps}$ で 1 例に $10 \mathrm{db}, 2$ 例 に $5 \mathrm{db}$ の上昇を認めた。刺㦸負荷 2 分後には多くは正 常值に回復したが，1 例 $2000 \mathrm{cps} て ゙ ~ 5 \mathrm{db} の$ 上昇が残存 していた.4 号受話器の場合は刺踣負莎值後では 4000 cps に和いて 2 例に 5 及び $10 \mathrm{db}, 2000 \mathrm{cps}$ では 2 例に $5 \mathrm{db}, 1000 \mathrm{cps}$ では3例に $5 \mathrm{db}$ の域值上昇瑟めた。 又 刺㦸負荷 2 分後では 1 例のみ $2000 \mathrm{cps}$ 及び $4000 \mathrm{cps}$ に 䋇てな和 $5 \mathrm{db}$ の上昇を示したが 5 分後には耐受話器

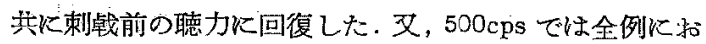
いて刺皒に上る聴力の低下が羿められなかいた。次に信 号音による域僆の変動学みると第 14 表に示す如くであ

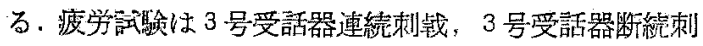

第 14 表

\begin{tabular}{|c|c|c|c|c|c|c|c|c|c|c|c|c|c|}
\hline \multirow{2}{*}{\multicolumn{2}{|c|}{ (5) }} & \multicolumn{4}{|c|}{ 3号受話器要琒 } & \multicolumn{4}{|c|}{ 3是受話器断统 } & \multicolumn{4}{|c|}{ 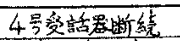 } \\
\hline & & 500 & 1000 & 2000 & 4000 & 500 & 10001 & 2000 & 6000 & 500 & 7000 & & 400 \\
\hline \multirow{3}{*}{$S . F$} & 直后 & 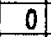 & 5 & 10 & 0 & 5 & $r$ & & 5 & & 3 & & \\
\hline & 2015 & & & & & & & & & & 0 & & \\
\hline & 5分 & & & & & & & & & & & & \\
\hline \multirow{3}{*}{$1 . !$} & 西应 & & & 10 & & & & 20 & 10 & 10 & 0 & 10 & $\underline{c}$ \\
\hline & ?分在 & 0 & 5 & 10 & & 5 & 5 & 15 & 10 & $F$ & 0 & 10 & \\
\hline & 5 公官 & 0 & 0 & 0 & & & $a$ & -1 & & & 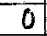 & & \\
\hline \multirow{3}{*}{ N.T } & 直后 & 0 & 0 & 15 & & 5 & 10 & 15 & & 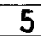 & 10 & 10 & \\
\hline & 2分后 & 0 & 5 & 10 & 5 & 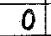 & 5 & 5 & 3 & 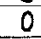 & 5 & 5 & \\
\hline & 59 & 0 & 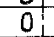 & & 0 & 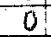 & 0 & & & 0 & & 1 & \\
\hline
\end{tabular}

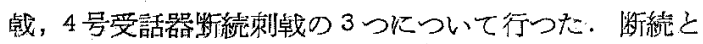

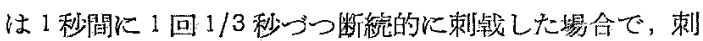

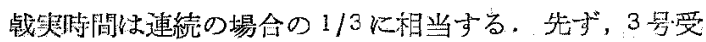

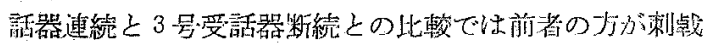

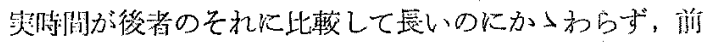

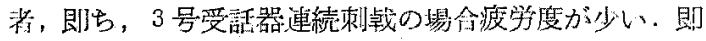

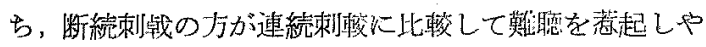

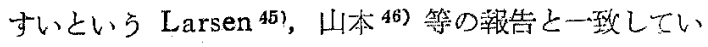

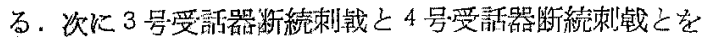
此輍すれば，捘者は前者に比し疲等度大であり，又これ

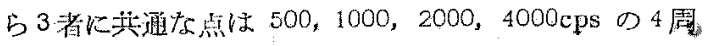

波数のちち，疫労の最も大きいものは $2000 \mathrm{cps}$ で 1000 ， $4000 \mathrm{cps}$ はこれK次ぎ $500 \mathrm{cps}$ が最も少なからた，但し

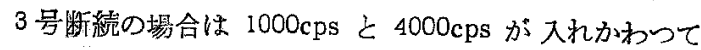
いる，この場合の信号音の大きさ，感覚単位上ほ $100 \mathrm{db}$ であつた。この程度の侵号音は回線により，なた

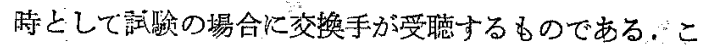
れらの音㢣をりナグラスによつて分断したが Click は 第 10 図，第11 図に示与如く比較的高音部にスペクトル

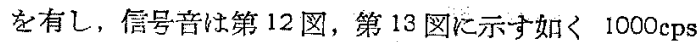
附近及びそれ以下に主として Energy が集中している。

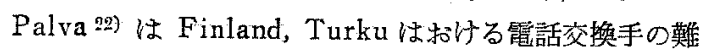
聴で $2000 \mathrm{cps}$ 低下が比较的多いのは交換手の便用して いる受話器の特性によるとしている．我国で以前使用し ていた 3号受話器伤 14 図に示才如く $1000 \mathrm{eps}$ 附近に Peak を有しており Finland の受話器の特性乙類似し

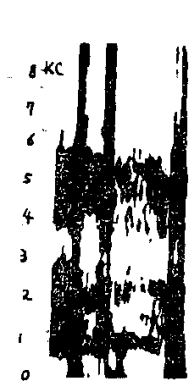

第 10 図

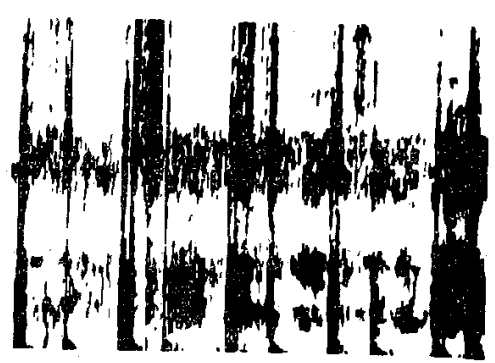

第 11 図

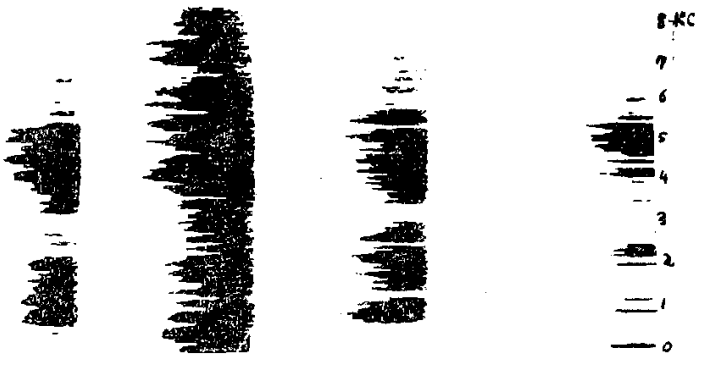

第 12 図

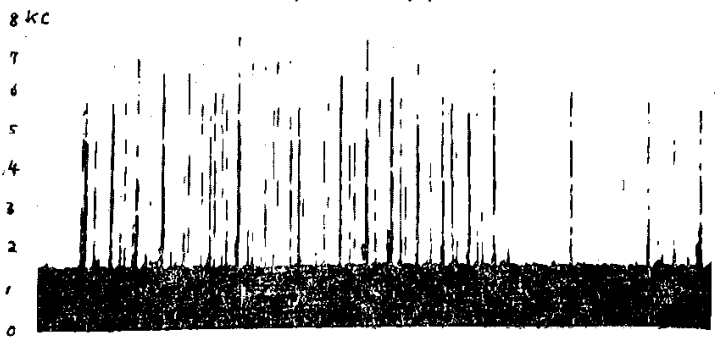


第 13 図
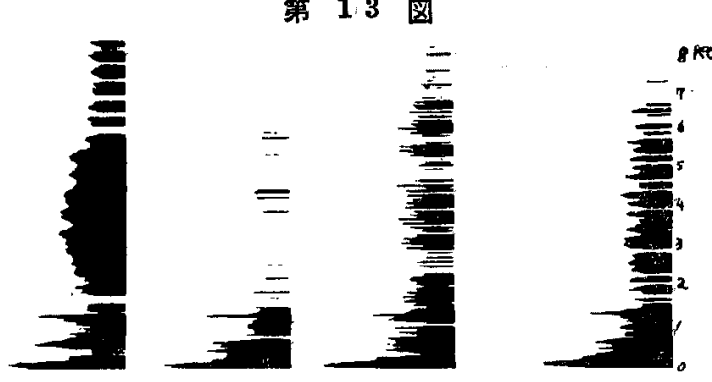

第 14 図

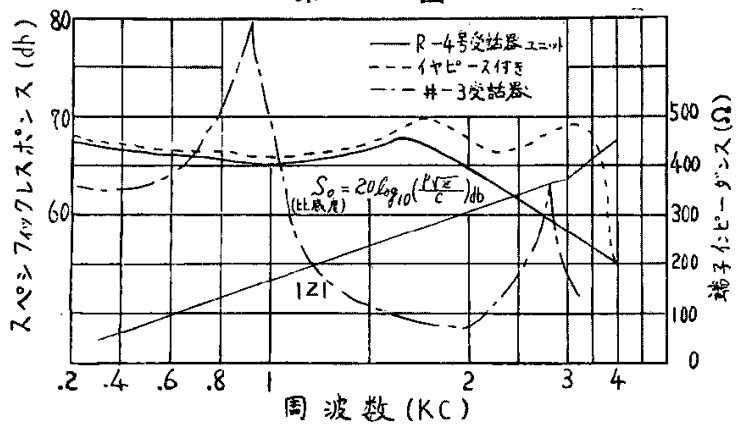

ている. 従って3 号受話器による $\mathrm{C}_{4}$ Dip はこの特性 でも一応説明づけられると思れれた，ところで我国で現 在便用している 4 号受話器は米国のそれと共に圮界で最 も僸れた受話器であり47)，3号受話器に比較して比赅的 Flat な特性を有している．私はこの 4 号受詰器のみを 使用した電話交換手に叔いてる，前述したよらにやはり 主として $2000 \mathrm{cps}$ の低下した難㯖6耳を発見した。従 つてこのことは受話器自身の特性のみで説明できない。 この Dip の成立に関しては以下述べる諸氏の产歌成續 に関連があるものと考えられる. 即ち，Davis, Morgan

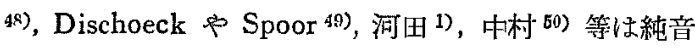
による実駼成績に柌いて聴覚疲学が刺㦸音より半ォタタ ーブ乃至 2 オーターブ高音にずれるとしている。また 森岡 ${ }^{51)}$ は褓合純音の暴露による聴覚障得の奏験で，丁 度成分純音のみによる聴力撌失が単純に複合されたよう な形をとるとして扣り，原田 ${ }^{60)} 1000 \mathrm{cps}$ より比較

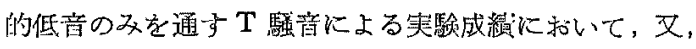

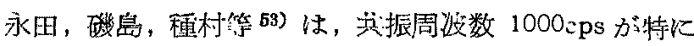

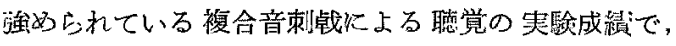
$2000 \mathrm{cps}$ に変覀が著明であるとしている，受話器上り発 せられる音のらち，特に，難欴を㟟起易いと思われる信 号韻は前述せる如く，凡气 $1000 \mathrm{cps}$ 附近及びそれ以下

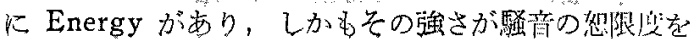

越党る埸合が存在する事実，又，古武籍8）に上れば受 誳器上り受聴される音声は普通の男声及び男声の大声で はその最大做が先れぞれ $94 \mathrm{db}$ 及び $99 \mathrm{db}$ むり，音声 の場命でもやはり恕限度を越党る承があり，且つこの音 声のスペクトルは三浦(2) の实䮄に上机ば，男声，女声 共に $1000 \mathrm{cps}$ 以下に主として Energy が集中している 事彗及び著者の行つた Click 及び信号音の聴鸴疲労害

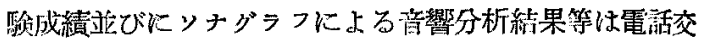

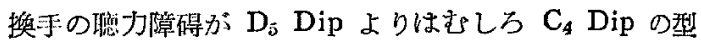
で発生し易い傾向と関係あるものと考学られる。

\section{VI. 結 論}

昭和 31 年 115名, 昭和32年 134 名, 昭和 33 年 133 名 の青森局電話烄换手及び昭和 33 年 16 名の弘前局電話 交换手に対し聴力榆查を行い次の結果を得た。

1. 難蚛の発現率はそれぞれ，10.9\%，14.2\%，17.7\%， $22.4 \%$ (耳数) であり，その中，感音系難聴がいずれも 80\% 以上を占め更に感音系難腹のうち，受話器による と思われる難聴が $50 \%$ 以上をしめていた。

2. 受話器に上る難聴のみについて以下の成績を得た。 a 難聴は平均恥力損烍 $30 \mathrm{db}$ 以内の軽度のものが 90 $\%$ 以上であった。

$\mathrm{b}$ 勤務年数 5 年以上以䧼聴が多からた。

$\mathrm{c}$ 勤務年数 5 年末满の者では平坛嵭力擅失 $10 \mathrm{db}$ 以内 の軽度䩿䵊者が多く $30 \mathrm{db}$ 以上の聴力損失者は認めら れなからた。

$\mathrm{d}$ 聴力型では Dip 型が最も多く，次いでV 型，U型， 濑傾型の順であり，Dip 型の細別では $\mathrm{C}_{4}$ Dip が大多数 を占め， $\mathrm{C}_{5}$ Dip は比較的少なからた。

e 受話器一側便用者は両側交互使用者より難聴の発現 率が大であった。

f 2 年閆の観察に出いて 500, 1000, 2000, 4000cps の 中， $2000 \mathrm{cps}$ の低下したものが最も多いが 4 周波数平均 $15 \mathrm{db}$ 以上改善及び昰化を示したるのはなからた。

g 精密检查成績では恩地法, DL 法兵半数以上飞 拈 いて陽性であつた。会話率による語音明嘹度検查成績を 見るに純音暗力損失軽度の例では，語音出力 $40 \mathrm{db}$ 飞招 いてはその半数以上に明膫度の低下が認められ，純音港 力撌失中等度以上の3例は語音出力 $90 \mathrm{db}$ において子明 瞭度は低下していた

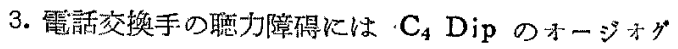
ラム走示すのが多いのがその特徽である。このことは 受聴する信号音及び音声等の主なる音響 Energyが1000

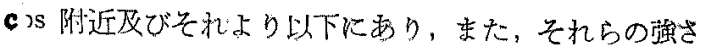




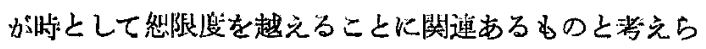
れる。

\section{文献}

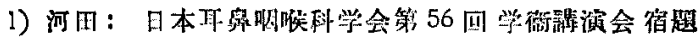

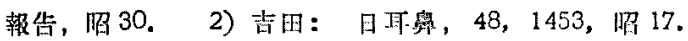
3）大沢，法水：逝倍医学，1，39，肾 24, 4) 法水,

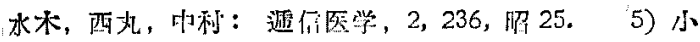

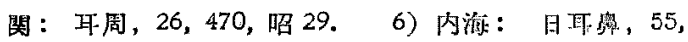
466, 昭 17. 7) 占武, 須川, 武田, 叱田: 労㗢科学,

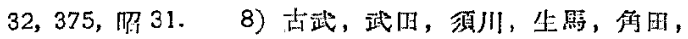

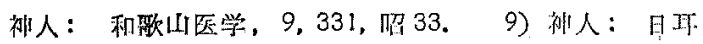

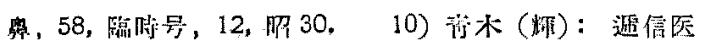

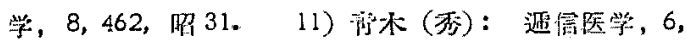

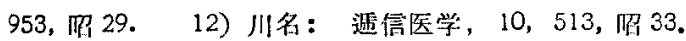

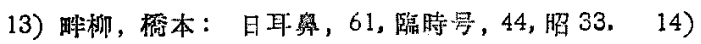
荻野：日耳鬼，61, 臨時号，46. 昭 33. 15）立禾, 坂 本, 萩野: 耳崌揭載予定. 16) 立木, 湯本, 渡辺: 耳喉，30，552，昭 30，17）恩地：耳喉，26，145，昭

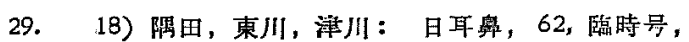
94. 昭 34. 19) 聴力測定法の親篗：日本オージオ口 夲一学会発行, 昭 30. 20) 保野, 田中, 井尻: 耳腒, 27,622 , 炤 30。21) 久保, 沢田, 菻, 志多: 日耳鼻, 61, 榢時号, 42, 昭 33. 22) Palva, T: Acta Otolaryng, 47, 510, 1957. 23) 健㻖管理䘽定：日本雪信霓 嗙公社, 昭 32. 24) Report of Council on Physical Medicine: J.A.M.A. 133, 396, 1947. 25) 娥業性获倠 聴実態謂查報告：労徵省，昭 27.26$)$ Rosenblith, W.A. Stevens, K.M.: (Sataofe 著 Industrial Deafness Mc Graw-Hill Book Company Inc. 1957 s. 用). 27) 山本: 労憉科学, 32, 361, 昭 27 . 28) Coleman, J.: The Eye, Ear, Nose \& Throat Monthly 68,645, 1958, 29) 西部, 神目, 鬼島, 㮐井:

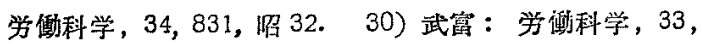
299, 昭 32. 31) 坂口：耳喉, 25, 324, 昭 28. 32) 虽永：日耳睤，59，467, 昭 26 . 33) Siirara. U. La- hikainen A.L.: Acta Otolaryng. Suppl. 67, 107, 1948.

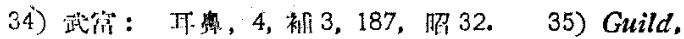
S.R.: Laryngoscope. 42, 821, 1932. 36) Huizing, H.C.: Acta Otolaryng, 40, 51, 1951. 37) 切替:

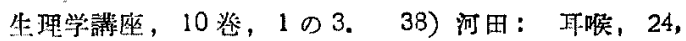

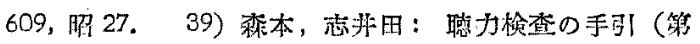

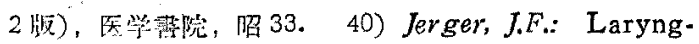
oscope. 62,1316, 1952, . 41) 恩地：勿喉，24，13,

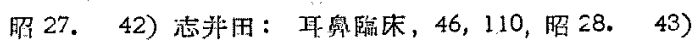

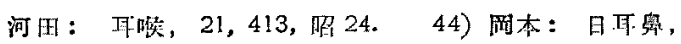
54, 181, 炤 26. 45) Larsen, B.: Acta Otolaryng Vol. 41, 139, 1952.46) 山本: 学㖶科学, 30, 254,

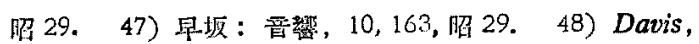
H. et al: Acta Otolaryng. Suppl. 88, 1950. 49) Van Dishoeck, H.A.E.: Spoor. A, Laryngoscope. 68,645, 1958.50）中利（蜸）：日耳睤，59，1920， 昭 31，51）箖岡：学働科学，30,254, 昭 29.52$)$ 原

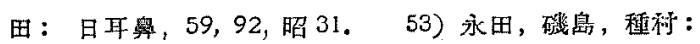

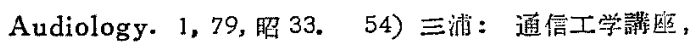
9-A，共立出限，昭 30 .

終に゙㜔み，本研究にあたつて，終始兴切なる

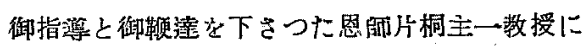
深藅なる感謝の意を表します、なを，種る御助 言をいたぶいた立本孝助教授，教室の宮野和夫

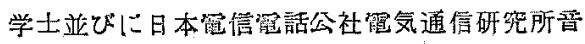
留研究空の三浦整敏主任及び本研究に拹力して

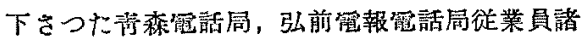
氏に厚く感謿致します。

本論文の聓旨は昭和 34 年 2 月，日本耳舞咽 㘈科学会東北地方会第 105 回例会及び昭和 34 年 4 月萿信医等会 10 回総会に占いてロ述し t.

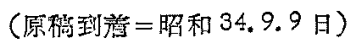

